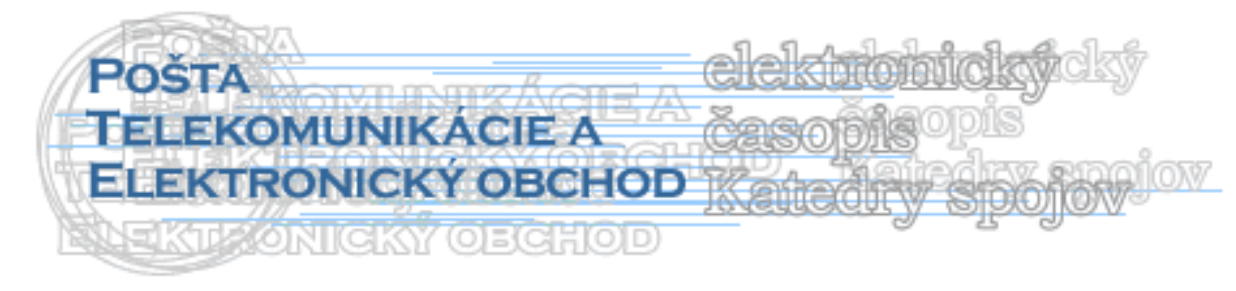

\title{
POSTAVENIE SPOLOČNOSTI DHL NA TRHU FREIGHT FORWARDINGU
}

\author{
Lubomír Bombala*
}

Úvod

Široká verejnost' spája často firmu ako DHL výhradne so službou DHL Express, tzn. kuriérskymi službami spojenými s doručovaním dokumentov a baličkov. Podstatnou súčast'ou podnikania DHL je aj DHL Global Forwarding, pričom v oblasti leteckého a námorného forwardingu je DHL lídrom svojho segmentu.

Vzhl'adom na pomerne plynulý hospodársky rast patril freight forwarding $\mathrm{v}$ tejto dekáde k rýchlo rastúcim segmentom logistického podnikania. Rovnako ako iné odvetvia je aj toto odvetvie zasiahnuté globálnou finančnou krízou a poklesom objemu prepravovaného tovaru.

V súvislosti s freight forwardingom či skrátene forwardingom sa často používa aj termín "space brokering“, ktorý vyjadruje takisto podstatu spomenutej služby, ktorá nie je založená na fyzickej doprave tovarov, ktorú zabezpečuje zmluvná strana, ale na sprostredkovaní tejto prepravy. Preprava je teda zabezpečená zmluvným dopravcom, s ktorým má forwardingová spoločnost' uzavretý kontrakt. Podstata kontraktu a jeho výhodnost' je samozrejme spojená s množstvom a frekvenciou prepravy tovaru, ktorú forwardingová spoločnost' sprostredkuje. Rovnako tak forwardingová spoločnost' s rastúcim objemom a pravidelnou frekvenciou prepravy zásielok môže získat' výhody v podobe nižších poplatkov za prepravu. V tejto súvislosti treba chápat' aj podstatu forwardingovej spoločnosti, ktorá pre svojich zákazníkov zabezpečuje potrebnú administráciu, vystavuje faktúry, má informačný systém, ktorý umožňuje optimálnych spôsobom využit' kontraktované dopravné spoločnosti, pričom taktiež rešpektuje hl'adisko vel'kosti zákazníka a množstva prepraveného tovaru, na základe čoho určuje výslednú cenu za prepravený tovar.

Freight forwarder (často iba forwarder alebo zasielatel') je poskytovatel' logistických riešení s využitím tretej strany. Ked'že ako poskytovatel' služby nevlastní dopravné prostriedky, prepravu tovarov zabezpečujú iní dopravcovia, u ktorých má forwarder zmluvne alebo iným spôsobom zaistené dopravné kapacity na prepravu tovaru. Typicky sa jedná o dopravcov námorných, leteckých, kamiónových a železničných. V tejto súvislosti treba upozornit' na fakt, že forwardingová spoločnost' samozrejme môže vlastnit' dopravné prostriedky, z hl'adiska optimalizácie nákladov má však pre takúto spoločnost' ich vlastníctvo ekonomický prínos iba pri pravidelnej preprave vel'kého množstva tovaru na rovnakej trase.

Transshipment (Transhipment) je zásielka tovaru do medzi destinácie a odtial' do konečnej destinácie.

\footnotetext{
* Ing. L'ubomír Bombala, DHL IT Services Europe, V Parku 2308/10, 14800 Praha 4, ext. doktorand, Katedra spojov, FPEDAS, ŽU v Žiline, tel: +420 288802 185, e-mail: lubomir.bombala@dhl.com
} 
Common carrier je spoločnost', ktorá dopravuje l’udí, tovar a ponúka svoje služby širokej verejnosti na základe licencie alebo na základe povolenia poskytnutých regulačným orgánom. Common carrier musí preukázat' regulačnému orgánu, že je schopný poskytovat' služby, na ktoré žiada alebo má udelené licenciu či povolenie.

Freight forwarder typicky organizuje prepravu nákladu do medzinárodných destinácií. Medzinárodný freight forwarder má znalosti a prostriedky, ktoré mu umožňujú pripravit' a vybavit' potrebnú dokumentáciu, ktorá sprevádza prepravu nákladu. Rovnako zabezpečujú d’alšie aktivity, ktoré sprevádzajú medzinárodnú prepravu, ako je komunikácia s colnými a daňovými úradmi a pod.

Typickými dokumentmi, ktoré pri preprave tovaru zabezpečuje freight forwarder sú komerčná faktúra, exportná deklarácia vývozcu a d’alšie dokumenty vyžadované dopravcom alebo krajinou exportu, importu alebo transhipmentu. Mnohé z týchto informácií sú poskytované výlučne $\mathrm{v}$ elektronickej podobe. V tomto zmysle je freight forwarder držitel'om licencie pre freight forwarding, pričom jeho hlavným vkladom do podnikania je siet' pobočiek, kvalifikovaný personál a informačný systém, ktorý zabezpečuje podstatnú čast' dokumentácie a administrácie prepravy nákladu.

\section{DHL Global Forwarding (DGF)}

Lídrom na trhu globálnych forwardingových spoločností z pohl’adu trhového podielu je DHL. Divízia DGF je zameraná predovšetkým na letecký a námorný forwarding. K d’alším významným spoločnostiam patrí DB Logistics (Schenker), Kuehne \& Nagel a Panalpina.

DGF je súčast'ou DPWN (Deutsche Post World Net), ktorá je okrem poštových služieb (Deutsche Post) a finančných služieb (Postbank), poskytovatel'om širokej škály kuriérskych a logistických služieb v troch divíziách:

1. Express

2. Global Forwarding, Freight

3. Supply chain, Corporate Information Solutions

Postavenie a význam jednotlivých súčastí tvoriacich DPWN je uvedený v tabul'ke č. 1 .

Tab. 1 Vybrané ekonomické charakteristiky spoločnosti DPWN r. 2007 (DPWN annual report)

\begin{tabular}{|c|c|c|c|}
\hline \multicolumn{5}{|c|}{ Deustche Post World Net } \\
\hline Mail & Express & Logistics & Financial Services \\
\hline Deutsche Post & \multicolumn{2}{|c|}{ DHL } & Postbank \\
\hline \multicolumn{5}{|c|}{ Obrat v miliónoch (EUR) } \\
\hline 15484 & 13874 & 25739 & 10426 \\
\hline \multicolumn{5}{|c|}{ Podiel na celkovom obrate v \% } \\
\hline & 21,8 & 40,5 & 16,4 \\
\hline \multicolumn{5}{|c|}{ Zisk (EBIT) v miliónoch EUR } \\
\hline & 174 & 957 & 1076 \\
\hline
\end{tabular}

Podl'a údajov z roku 2007 bola spoločnost' DHL:

- najväčší svetový poskytovatel' logistických služieb s trhovým podielom 6,2 \%, 
- najväčší svetový poskytovatel' služieb leteckého freight forwardingu s trhovým podielom $11,9 \%$ a

- najväčší svetový poskytovatel' služieb námorného freight forwardingu $\mathrm{s}$ trhovým podielom $9,3 \%$.

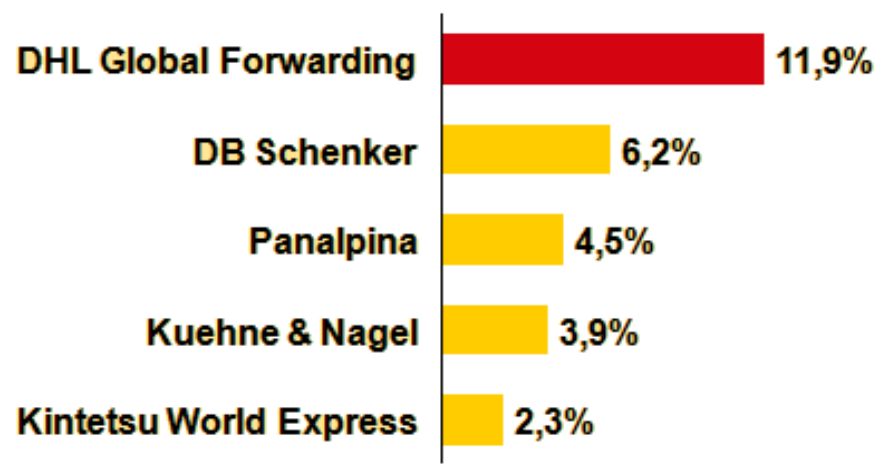

Obr. 1 Trhový podiel najväčších spoločností na globálnom leteckom freight forwardingu v r. 2007

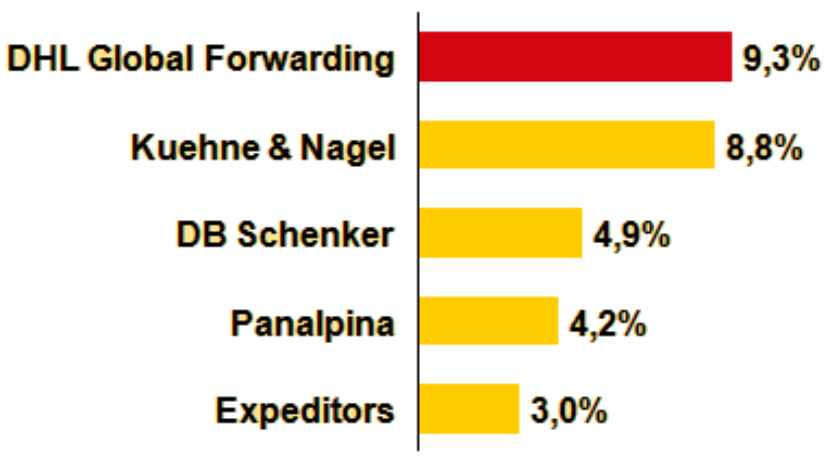

Obr. 2. Trhový podiel najväčších spoločností na globálnom námornom freight forwardingu v r. 2007

DGF zabezpečuje pre svojich zákazníkov plynulý tok tovarov a služieb naprieč globálnou siet'ou dodávatel'ov. Umožňuje spoluprácu poskytovatel'ov, dopravcov, colných agentov a koncových užívatel'ov. Ponúka úplnú sadu dopravných riešení bez ohl'adu na to, o aký typ tovaru sa jedná, flexibilné riešenia, vysokú úroveň znalostí colných procedúr v USA a Kanade, dodržiavanie platných regulácií a jedinečný informačný systém.

DGF má okolo 3000 logistických zariadení vo viac ako 220 krajinách, ktoré zabezpečujú riešenia pre:

- Námorné dopravné služby

Profitujú predovšetkým z vnútrozemskej logistiky DHL, optimálneho smerovania tokov, vd'aka čomu sú prepravované toky tovarov plynulé.

- Letecké dopravné služby

Umožňujú preferovanie dopravcov, konkurencieschopné prepravné náklady s využitím tímov, ktoré doručia tovar až ku dverám.

- Importné služby

Využívajú výhodu dlhodobých skúseností z oblasti medzinárodnej regulácie, colníctva, odvetvových štandardov, reportovania a pod.

- Vnútroštátne služby 
Predstavujú jeden zdroj pre všetky dopravné a logistické potreby v Severnej Amerike, ponúkajú flexibilné riešenia prepravy t’ažkých leteckých a pozemných nákladov

\section{- Medzinárodný ret'azec dodávatel'ov}

Manažment komplexného, celosvetového ret’azca dodávatel'ov je vd'aka tejto službe ovel’a jednoduchší. Pridaná hodnota sa nachádza práve v manažmente toku tovarov a informácií z bodu výroby do bodu predaja.

- Konsolidované distribučné služby

Najrýchlejší spôsob ako dostat' tovar z bodu výroby do bodu predaja - jeden kontaktný bod, jedna faktúra, jedna jednotka pre rýchlejšie preclenie, nižšie colné poplatky a menšie riziko zničenia alebo straty.

- Služby na severnej a južnej hranici (v rámci zoskupenia NAFTA)

Ponúka v danej oblasti neporovnatel'nú skúsenost' v bezproblémovom vybavení zásielok importovaných do USA z Kanady a Mexika.

- Priemyselné projekty

Zabezpečuje bezpečnú spol'ahlivú dodávku komplexných, t’ažkých a neobvyklých zásielok k priemyselným lokalitám so skúsenost’ou v oblasti t’ažby, s ropou a plynom.

DGF ponúka rozsiahly súbor informačných nástrojov a aplikácií, ktoré zabezpečujú globálnu dostupnost' a okamžitý prístup k informáciám o zásielkach a dostupnom inventári, všetko v reálnom čase, 24 hodín denne a 7 dní v týždni.

\section{Záver}

Výhodou vel'kých forwardingových spoločností ako je napr. DGF je nielen ich možnost' zoskupovat' malé zásielky do väčších, a tak optimalizovat' náklady na prepravu, ale aj do istej miery pravidelný objem prepraveného tovaru medzi dôležitými obchodnými centrami. To im umožňuje mat' kapacity u dopravcu rezervované skôr, ako ich o to požiada samotný zákazník. Rovnako majú vd’aka prepravovaným objemom výhodu v operatívnom obsadzovaní vol’ných dopravných kapacít. Výhoda menších spoločností je predovšetkým v ich špecializácii na konkrétneho zákazníka, konkrétny spôsob dopravy či konkrétne destinácie.

Freight Forwarding predstavuje komplexnú službu pre zákazníka. Z pohl’adu dopravcu predstavuje forwardingová spoločnost' outsourcing všetkých činností od vzt'ahov so zákazníkom, fakturáciu, reklamácie, informačný systém, správa pobočiek. V podstate ako zákazník dopravnej spoločnosti vystupuje freight forwarder, čo umožňuje dopravnej spoločnosti sústredenie sa na samotnú prepravu a zužuje množstvo vykonávaných činností.

Rovnaké výhody v podobe outsourcingu viacerých činností súvisiacich s exportom a importom tovaru, ktoré si vyžadujú nielen dodatočné l'udské zdroje a materiálne zdroje, ale aj vysokú úroveň znalostí v prudko sa meniacich trhových podmienkach, prináša táto služba aj pre zákazníkov.

\section{Literatúra a použité zdroje:}

1. $\quad$ www.bifa.org

2. www.fiata.com

3. www.dhl.com

4. http://www.iccwbo.org/incoterms/id3040/index.html

5. http://www.tradeyorkshire.com/downloads/freight\%20forwarding.pdf

6. http://www.clecat.org/

7. www.zlz.sk

8. http://www.dpwn.de/ 